UDC 624.04

\title{
Effect of joint stiffness and flexibility on the design of reinforced cement concrete structure
}

\author{
Govind P. Lamichhane*, Prajwal Giri \\ Pokhara University, Pokhara Metropolitan City-30, Lekhnath, Kaski, Nepal, Post Box: 427 \\ *govindkhec@gmail.com
}

Article history:

Received: November 12, 2019

Revised: January 17, 2020

Accepted: January 27, 2020

\section{Abstract}

Relevance. A beam-column joint is a crucial zone in any frame structure that transmits the forces at the end of the members in the panel zone. The connection between the joints may be assumed as rigid or flexible one and it is not an ideal one to predict the actual behavior of the joint section. Methods. The displacement along the joint section is the most critical one that has to be taken care while designing the structure. In this paper, the flexibility of the reinforced concrete joints was studied under two different cases: in first phase, building having 3 storey including ground floor was taken and is analysed using SAP 2000 and secondly third floor shear wall with 1 hollow concrete mesh of column section was analyzed in same software and the flexibility of the joints was tested in terms of its stress and displacement parameters using different approaches such as link mass property, end length offset zone, panel zone rotational spring stiffness property. The results obtained from the two cases were analyzed with consideration of parametric study and variation of the stresses with displacement and are shown with comparative graphic.

Keywords: joint flexibility; end length offsets; rotational spring stiffness; link mass property

\section{Introduction}

Beam column is the most critical sections in any structural elements and the actual behavior of joints is difficult to idealize and model in real scenario. Generally, the connections between the joints are assumed either fully rigid or pinned, which is not an actual behavior to predict joints behavior according to previous investigations $[1 ; 2]$. Rigid joints does not allow any rotations between the connected members while pinned joints are characterized by the free rotational movement between the connected elements and prevents the transmission of bending moments. The intermediate which is non-zero and non-infinite stiffness is semi-rigid joints [3].

Govind Prasad Lamichhane, $\mathrm{PhD}$, Associate Professor, School of Engineering. Prajwal Giri, graduate in MSc. in Structural Engineering, School of Engineering. (C) Giri P., Prasad L.G., 2019 (C) () International License https://creativecommons.org/licenses/by/4.0/
The study conducted by Johnson and Hope [1] found that the pin joints are very unpredictable while the rigid joints are often too stiff in relation to their strength, and are expensive. Therefore, an ideal semirigid joint is required to consider for the structural design with a large rotational capacity and a predictable flexural strength. In 2005, Cabrero and Bayo [2] proposed a design method for semi-rigid joints incorporating the design examples for demonstrating the applicability of the proposed method. Their study concluded that the semi-rigid design is the most cost effective solution when it is compared with the traditional pinned and rigid joints.

A considerable amount of past research has studied the load-deformation behaviour of panel zones under both monotonic and cyclic loads, very little past research has studied the attachment of doubler plates to columns in the panel zone regions. Limited studies of doubler plates and attachment details were conducted [4-7]. However, this past research has not resulted in clear conclusions on the most effective 
methods of welding the doubler plate to the column. So, P.S. Shirsat \& M.D. Engelhardt [8], summarizes the results of preliminary analysis of doubler plate attachment details for the steel moment resisting frames using finite element modeling of a simplified representation of beam-to-column joint subjected to monotonic loading. Analysis cases with different doubler plate attachment details were studied.

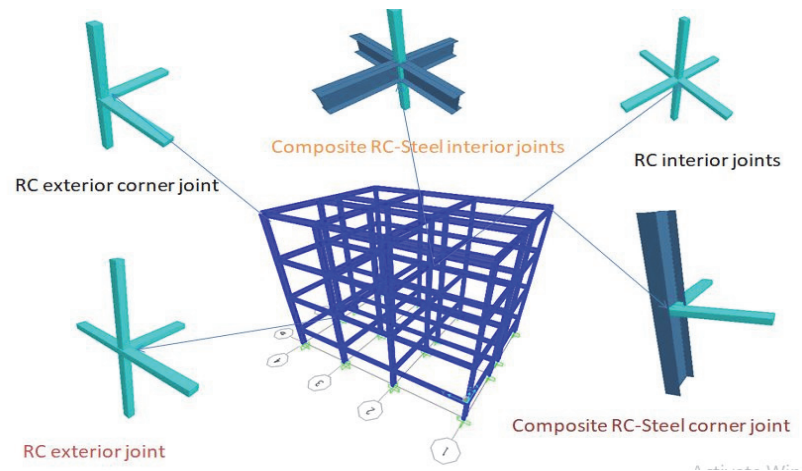

Figure 1. Different types of joint section in a structure (Rigid, semi-rigid, pinned)

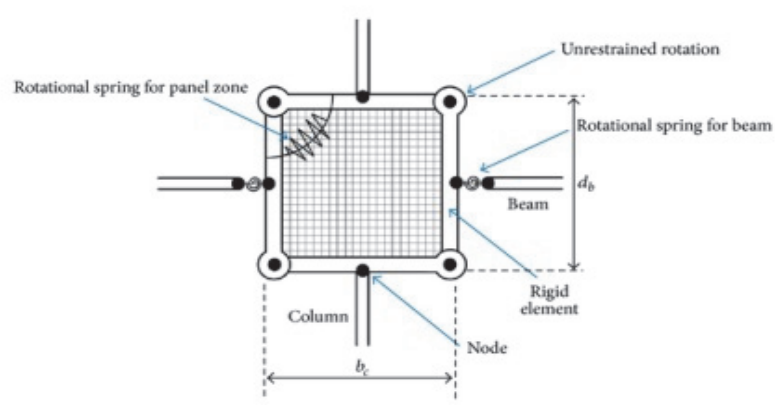

Figure 2. Krawinkler beam column joint flexibility model

Similarly, different types of linear centerline model (suitable for steel moment resisting frame), elastic model with panel zone (beams and columns reconnected via rigid links in a panel zone, and the crossroad hinge is connected via a spring with the stiffness of the panel zone), nonlinear model with panel zone (beam and column are connected by a link mass whose property may be fixed nonlinear to analyze the shear deformation behavior of the joints as proposed in [9], models a panel zone into 8 rigid bodies as shown in Figure 2. Actually, this model shows the least difference between the actual behavior of a structure and the behavior of the analytical model.).

Now different finite element analysis software has been used (SAP 2000, ETABS, STAAD-PRO) to test the joint flexibility using the different codes [11-18] by adopting the different flexural capacity ratio as 1.2, 1.4, and 1.3 respectively. Also IS 13920:1993 [13] draft version adopted 1.1, and IS 800:2007 [19] steel code adopted 1.2 and recently revised code IS 13920:2016 [13] has been used and this whole revision of code for the seismic joint flexibility of RCC member was reviewed by Pradip Sarkar et al. [20].

The displacement along the beam column connections is the most severe thing that affects mostly while designing and in this modeling different approaches are carried out to test the flexibility of joint section using link property, end length offset zone, panel zone rotational spring stiffness by modeling a frame structure and a shear panel zone consisting of lift section using a finite element software SAP 2000. Among all of these sections displacement and stress behavior of the joints is idealized and a conclusion is drawn out.

\section{Modeling approach}

To test the flexibility of the joint section SAP 2000 v20.2 is used applying two different frame structures to idealize it differently. In SAP 2000 there is different option to test the rigidity of joint behavior and each of them is explained simultaneously (Figure 3 ).

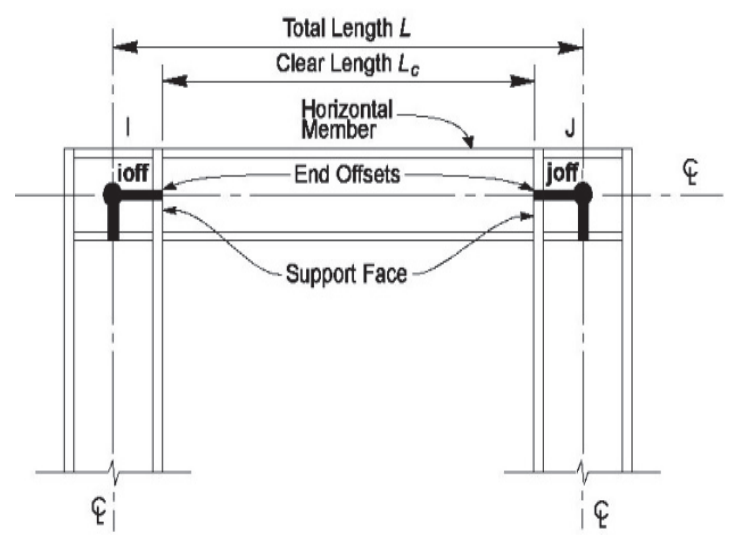

Figure 3. End length offset pane

Source: SAP manual CSI.

\subsection{End length offsets}

In SAP 2000 when we select all the joints and assign joints to end offsets then we can set according to the software automatically by varying the rigid zone factor or by directly giving the user defined offset value in either section of joints. The end offsets may be non-rigid, partially rigid or fully rigid. The rigidity of the joint is measured by using rigid zone factor. This factor specifies the fraction of the end offset length, measure from the frame element and is infinitely rigid. The remainder of the offset if any is assumed to have same flexibility as the beam. In the adjoining Figure 3: $L$ - total length of the element (inter-axial); $L_{c}$ - clear length, calculated as difference between total lengths with terminal segments $L_{c}=L-($ ioff + joff $)$. 


\subsection{Doubler plate thickness}

In a moment resisting steel or concrete frame subjected to lateral load either due to seismic or wind loads, the region of the column around the beam column joints known as panel zone will be subjected to high shear force. In some cases the region around the panel zone will be subjected to such high force that the column area must be reinforced to increase its strength or stiffness and one of the most common approaches to do so is to weld a plate in the column section known as doubler plate to the column. Welding doubler plate to the column increases the strength around the column section but it is difficult in reality where to apply the plate in column either horizontally or vertically around panel area. SAP 2000 allows the use of the doubler plate to the column by assigning the joints and giving the thickness of plate to such panel joints. However, during the past research it also showed that connecting the doubler plate along the vertical axis can add to the full strength of the joint as it prevents the lateral torsional buckling of the column rather than by adding it in horizontal way which adds to the little amount of stress only.

\subsection{Specified spring stiffness}

In frame structure when it is subjected to lateral load the resistance of the joint can be increased by assigning it to spring stiffness of certain mass in a panel zone. SAP 2000 allows the use of rotational spring stiffness in a panel zone along its major axis (about the local 3-axis of the column and panel zone) and minor axis (about the local 2-axis of the column and panel zone) of bending by giving the certain stiffness parameter. This allows the joints to be move uniformly when high seismic action is occurred and controls the drifts.

\subsection{Link mass property}

A link member connects the two objects together or a frame structure from one end to another end. Linear, non-linear and frequency dependent property can be assigned to a different six degree of freedoms which are internal to the link, including axial, shear and torsion element. SAP 2000 allows the use of specified link mass property in a panel zone area where mass and stiffness can be given to it, and it is different type such as linear, multi-linear elastic, plastic, damper etc. and according to the specified property we can change the degree of freedom of the system in it. In general a link mass allows the structure to deform elastically and plastically as specified.

\section{Geometry of the structure}

To analyze the flexibility of the joint frame structure is analyzed using two cases.

\subsection{Case 1}

$G+3$ story building is taken with the following dimensions and load assign as: building type - moment resistant $\mathrm{g}+3$ story building; beam size $-400 \times 300 \mathrm{~mm}$; column size $-300 \times 300 \mathrm{~mm}$; slab thickness $-150 \mathrm{~mm}$; waist slab thickness $-120 \mathrm{~mm}$, column height $2.8448 \mathrm{~m}$; wall load $-8.5 \mathrm{kn} / \mathrm{m}$.
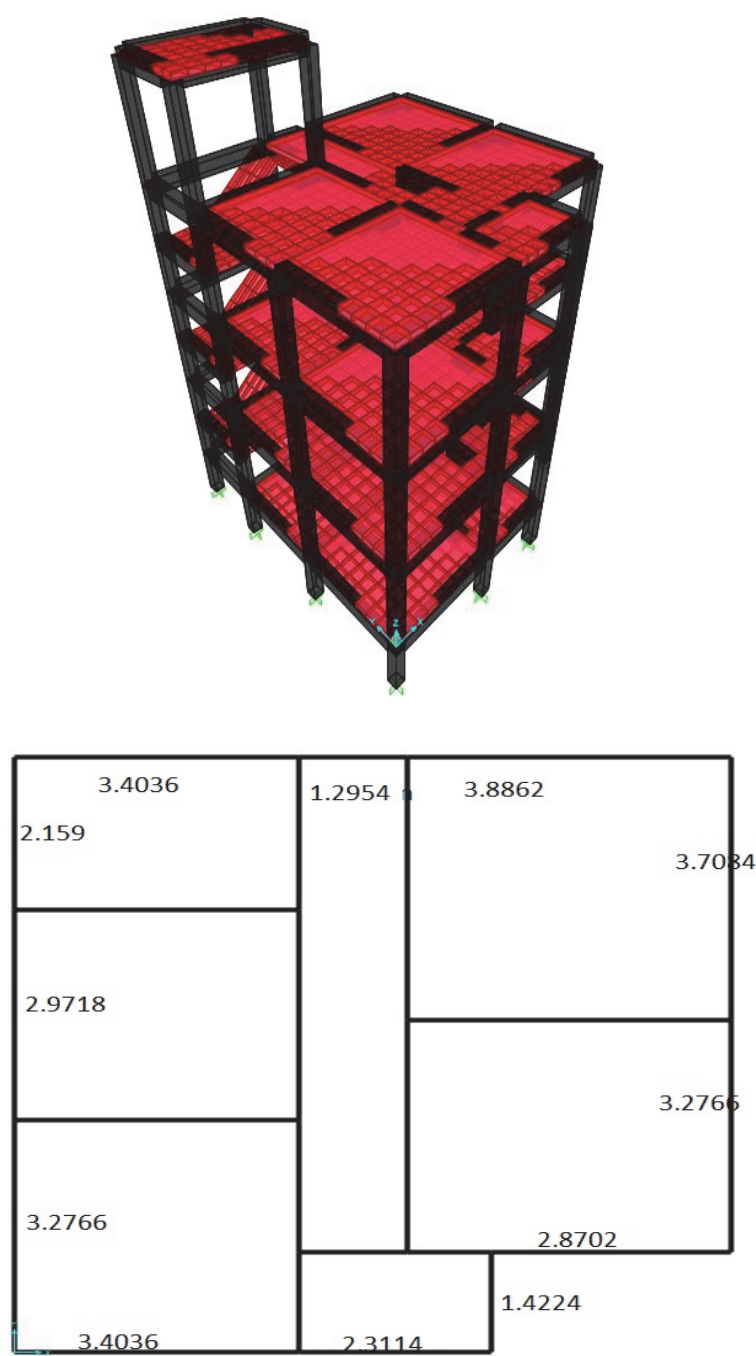

Figure 4. 3D view of the building and its plan view with the dimensions:

Live load $-2.5 \mathrm{KN} / \mathrm{m}^{2}$; floor finish load $-1 \mathrm{KN} / \mathrm{m}^{2}$; partition load - $1 \mathrm{KN} / \mathrm{m}^{2}$; staircase load $-2 \mathrm{KN} / \mathrm{m}^{2}$; EQ-X and EQ-Y applied along $\mathrm{X}$ and $\mathrm{Y}$ direction as per IS 1893-2002 and the load case is response spectrum load combination as per IS 456-2000.

\section{Results and discussions}

Variation of displacement with the increase in rigidity factor $(R F)$. The Table 1 and graph (Figure 5) shows the variation of displacement along the exterior corner joints (joint no. 122, 64, 63, 62, 3) with 
the increase in rigidity factor along the $\mathrm{X}$ and $\mathrm{Y}$ direction. Looking at the table and graph there is the corresponding decrease in displacement with the increase in rigidity factor along $\mathrm{X}$ and $\mathrm{Y}$ axis as with the increase in rigidity factor the connection of the joints along beam column junction changes from center to end which makes it rigid.

Table 1

Story displacement at exterior corner joint with the RF along the vertical axis along $X$ direction

\begin{tabular}{cccc}
\hline $\begin{array}{c}\text { Story } \\
\text { height }\end{array}$ & $\begin{array}{c}\text { Displacement } \\
\text { due to RF 0.5 }\end{array}$ & $\begin{array}{c}\text { Displacement } \\
\text { due to RF 0.75 }\end{array}$ & $\begin{array}{c}\text { Displacement } \\
\text { due RF 1 }\end{array}$ \\
\hline 0 & 1.0509 & 1.0454 & 1.0399 \\
2.8448 & 5.2771 & 5.2517 & 5.2261 \\
5.6896 & 9.1231 & 9.0767 & 9.0303 \\
8.5344 & 11.5585 & 11.5027 & 11.4468 \\
11.3792 & 13.5701 & 13.4965 & 13.4229 \\
\hline
\end{tabular}

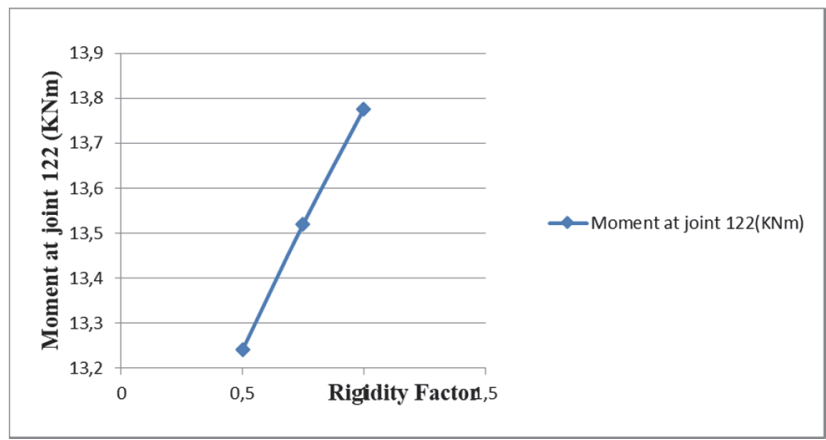

Figure 5. Moment vs. rigidity factor

Similarly the Figure 5 shows the variation of rigidity factor with moment at joint 122 along $\mathrm{X}$ direction. It is shown that there is increase in moment with the increase in rigidity factor. In general, at high rigidity there is decrease in displacement but it is very low which is not satisfactory too and also moment is also high and at low rigidity there will be high displacement and low moment which is also not satisfactory, so for designing it is recommended to use a rigidity factor of 0.5 for designing aspect.

Variation of displacement with the thickness of doubler plate. The Figure 6 shows the decreases in displacement at a particular joint (joint no. 122, 64, $63,62,3)$ with the increase in doubler plate thickness when all the rigid joints in panel area are assigned to a thickness of $0,50,150,250 \mathrm{~mm}$ respectively. This shows that the more the size of thickness of plate used then there is decreases in displacement but the choose of right amount of size becomes the necessary for the designing aspect.

Variation of drift with the rotational mass spring. Looking at the Table 2 and following graph (Figure 7) there is corresponding decreases in inter-story drift along the exterior corner joint with the increases in the stiffness of rotational spring of mass in the panel zone area. The drift first increases and moves down and it again increases as shown the graph (Figure 7). It also shows the corresponding decreases in displacement with the increases in spring stiffness when applied along major and minor axis.

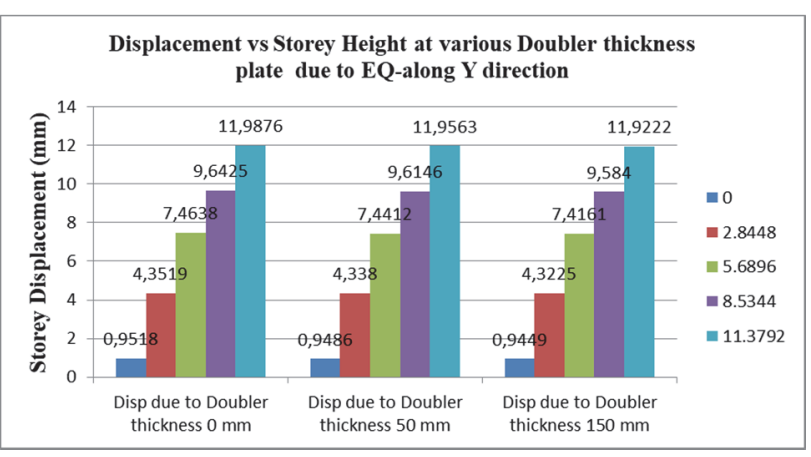

Figure 6. Displacement vs. story height at various doubler plate thicknesses along EQY direction

Table 2

Variations of drift with rotational spring mass

\begin{tabular}{ccccc}
\hline $\begin{array}{c}\text { Storey } \\
\text { height } \\
(\mathbf{m})\end{array}$ & $\begin{array}{c}\text { Drift } \\
\text { due to } \\
\text { stiffness } \\
\mathbf{2 K N -} \\
\mathbf{M} / \mathbf{r a d}\end{array}$ & $\begin{array}{c}\text { Drift } \\
\text { due to } \\
\text { stiffness } \\
\mathbf{1 0 0 K N -} \\
\mathbf{M} / \mathbf{r a d}\end{array}$ & $\begin{array}{c}\text { Drift } \\
\text { due to } \\
\text { stiffness } \\
\mathbf{1 0 0 0 K N -} \\
\mathbf{M} / \mathbf{r a d}\end{array}$ & $\begin{array}{c}\text { Drift } \\
\text { due to } \\
\text { stiffness } \\
\mathbf{2 0 0 0 K N -} \\
\mathbf{M} / \mathbf{r a d}\end{array}$ \\
\hline 0 & 1.4889 & 1.4876 & 1.4764 & 1.4585 \\
2.8448 & 5.3344 & 5.3292 & 5.2820 & 5.2074 \\
5.6896 & 4.8732 & 4.8682 & 4.8235 & 4.7531 \\
8.5344 & 3.0869 & 3.0839 & 3.0567 & 3.0158 \\
11.3792 & 4.5694 & 4.5529 & 4.4133 & 4.2176 \\
\hline
\end{tabular}

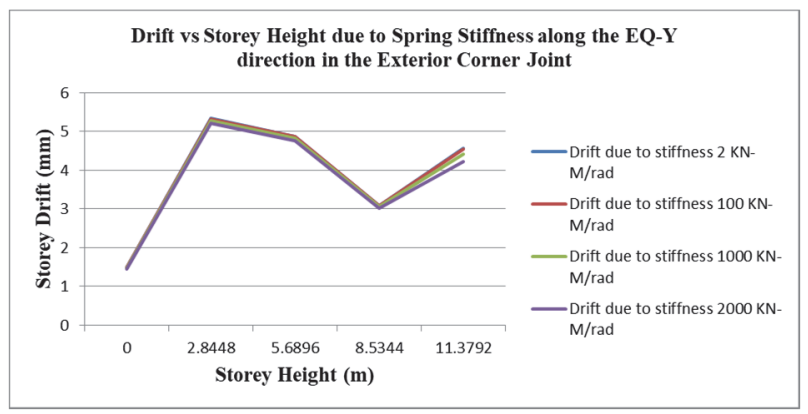

Figure 7. Drift vs. story height due to spring stiffness variation along EQY direction

Variation of displacement and drift due to link mass property in the panel zone. The two graph (Figures 8, 9)the increase in displacement and inter-story drift with the increase in link mass member used along the panel zone (joint no. 122, 64, 63, 62, 3). The link mass member of different weight were taken and link member is assigned multi-linear elastic member property to check 
its deformation and drift making the degree of freedom along $\mathrm{X}$ nonlinear. In both case drift and displacement increased as link member allows the joints to deform freely.

Table 3

Displacement variation with story height due to link mass laid along exterior joints in panel zone

\begin{tabular}{ccccc}
\hline $\begin{array}{c}\text { Storey } \\
\text { height } \\
(\mathbf{m})\end{array}$ & $\begin{array}{c}\text { Displace- } \\
\text { ment due } \\
\text { to mass } \\
\mathbf{1 0 0 ~ K g}\end{array}$ & $\begin{array}{c}\text { Displace- } \\
\text { ment due } \\
\text { to mass } \\
\mathbf{5 0 0 ~ K g}\end{array}$ & $\begin{array}{c}\text { Displace- } \\
\text { ment due } \\
\text { to mass } \\
\mathbf{1 0 0 0 ~ K g}\end{array}$ & $\begin{array}{c}\text { Displace- } \\
\text { ment due } \\
\text { to mass } \\
\mathbf{1 5 0 0 ~ K g}\end{array}$ \\
\hline 0 & 5.7956 & 16.8339 & 32.6885 & 48.6399 \\
2.8448 & 28.0819 & 83.633 & 164.3091 & 245.9528 \\
5.6896 & 47.6934 & 144.1691 & 285.359 & 426.9281 \\
8.5344 & 60.7955 & 184.4732 & 365.8733 & 547.4332 \\
11.3792 & 97.2976 & 294.3606 & 581.2367 & 869.9576 \\
\hline
\end{tabular}

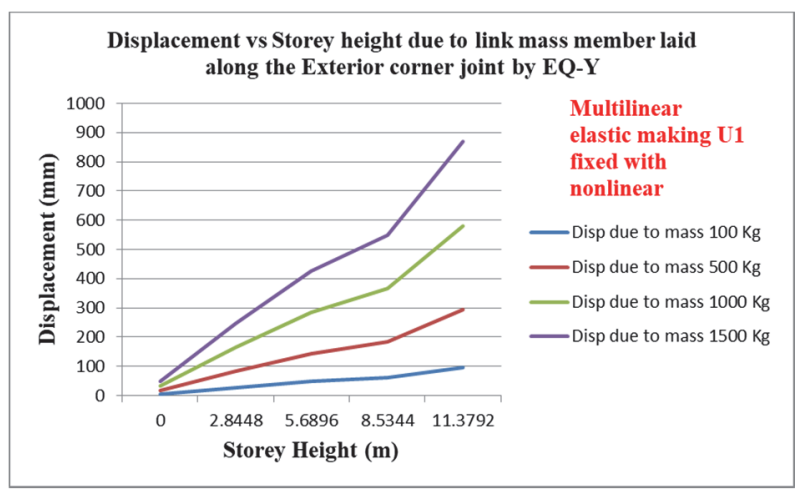

Figure 8. Displacement vs. story height along the exterior joint due to link mass variation at EQY direction

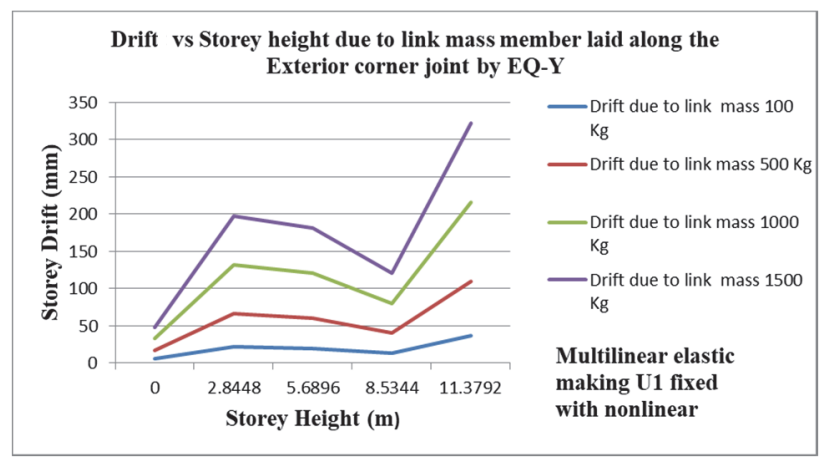

Figure 9. Drift vs. story height along the exterior joint due to link mass variation at EQY direction

Variation of displacement with the variation of placement of bottom tie beam. The graph (Figure 10)the variation of displacement at top story level at joint no 122 with the variation of the position of tie beam level at the bottom of the footing. The displacement first increases and then decreases and then increases again. Based on the variation of displacement above, the optimum minimum level of displacement at the top story is found when footing is at $0.1 \mathrm{~m}$ above its normal level. During the analysis the footing level is kept at $1.5 \mathrm{~m}$ below tie beam level.

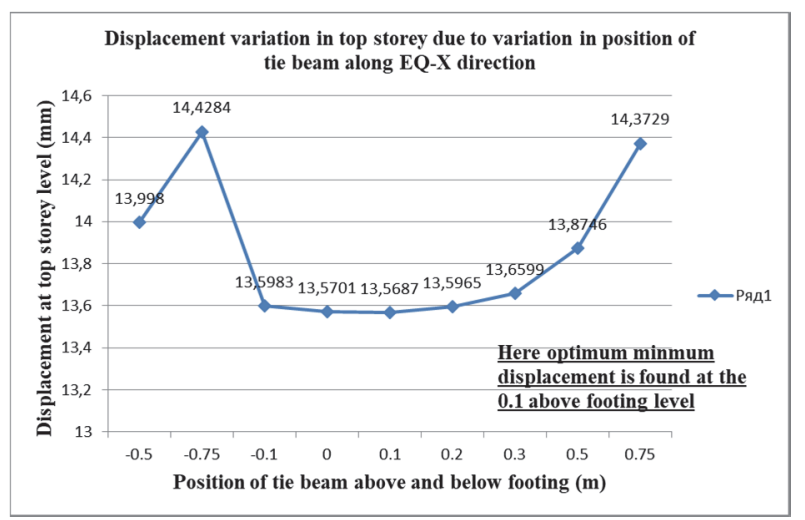

Figure 10.Variation in displacement at top level with the variation in the level of tie beam at bottom

\section{Conclusions}

After analyzing the above frame structure with the different supporting member in panel zone area the following conclusions were drawn:

1) the flexibility of the beam column joint connection decreases with the increases in rigid factor from non-rigidity to rigidity (from 0 to 1 ). So, from designing aspect of view semi-rigid connection is best suitable as both displacement and moment will be within in satisfactory range;

2) the displacement decreases with the increases in doubler plate thickness at a particular joint and the use of this plate can lead to prevention of high shear during high seismic force;

3 ) the displacement and inter-story decreases with the increase in mass of rotational spring stiffness along the panel zone area as the use of spring having high stiffness makes the joint member rigid and controls drift;

4) the drift and displacement increases with the use of specified link mass member along the panel zone area. Link member was assigned non-linearly to a degree of freedom along $\mathrm{X}$ axis and its property is assigned multi linear elastic constant and it showed the increases in drift and displacement. Similarly, we can test the same result by assigning the other property such as multi linear plastic, damper, etc. to test its shear and deformation capacity;

5) the displacement at the top level of building varies with the position of level of tie beam. It generally increases below the footing level and also increases above the footing but becomes at the optimum level a little above footing. 


\subsection{Case 2}

A shear wall consisting of lift on either side of column is done in $1 \mathrm{~m}$ length and a cubic section like a hollow mesh is prepared as shown below (Figure 11). The general property of shear wall structure is: building type - shear wall system consisting of lift element on either side of column; beam size $-400 \times 300 \mathrm{~mm}$; column size $-300 \times 300 \mathrm{~mm}$; live load $-10 \mathrm{KN} / \mathrm{m}^{2}$; floor finish and partition load $-3 \mathrm{KN} / \mathrm{m}^{2}$; slab thickness - M20; EQX and EQY applied along X and Y as per IS 1893-2002 (response spectrum function).
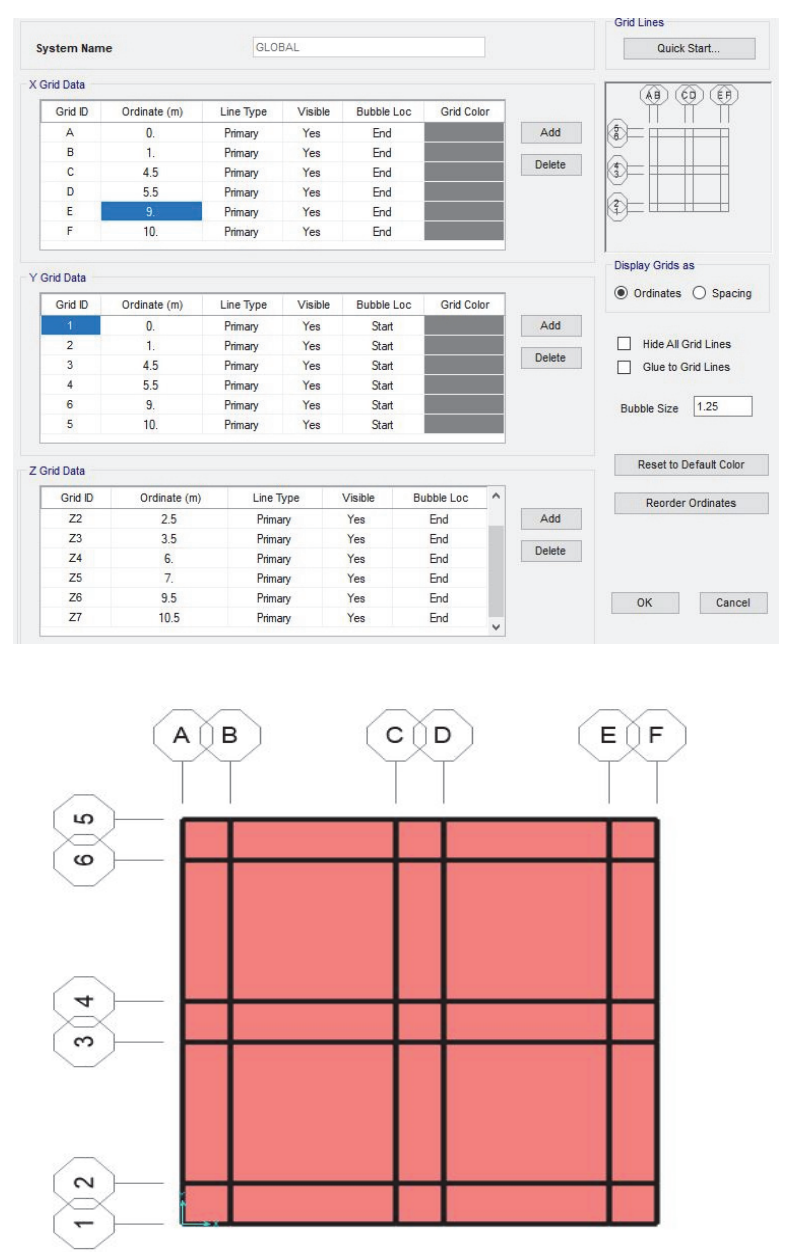

Figure 11. Geometric grid and the plan view of shear wall system

\section{Results and discussions of shear wall system}

Variation of inter-story drift with the increase in thickness of shear wall. The graph (Figure 12) the variation of drift at a joint (joint no. 255, 149, 14, 7) along a vertical axis in exterior corner joints. With the increase in shear wall thickness there is corresponding decrease in drift along the joints. But very high thickness is also not desirable one so thickness should be such which is best applicable from designing aspects too.
Table 4

The variation of inter-story drift with the increase in thickness of shear wall

\begin{tabular}{cccc}
\hline $\begin{array}{c}\text { Storey } \\
\text { height } \\
\text { (m) }\end{array}$ & $\begin{array}{c}\text { Drift due to } \\
\text { shear wall } \\
\text { thickness 0.4 } \mathbf{~ m}\end{array}$ & $\begin{array}{c}\text { Drift due to } \\
\text { shear wall } \\
\text { thickness 0.2m }\end{array}$ & $\begin{array}{c}\text { Drift due to } \\
\text { shear wall } \\
\text { thickness 0.49 } \mathbf{~ m}\end{array}$ \\
\hline 0 & 0.02537 & 0.03338 & 0.00173 \\
3.5 & 0.16388 & 0.22727 & 0.01576 \\
7 & 0.15526 & 0.22077 & 0.02157 \\
10.5 & 0.11022 & 0.15543 & 0.02235 \\
\hline
\end{tabular}

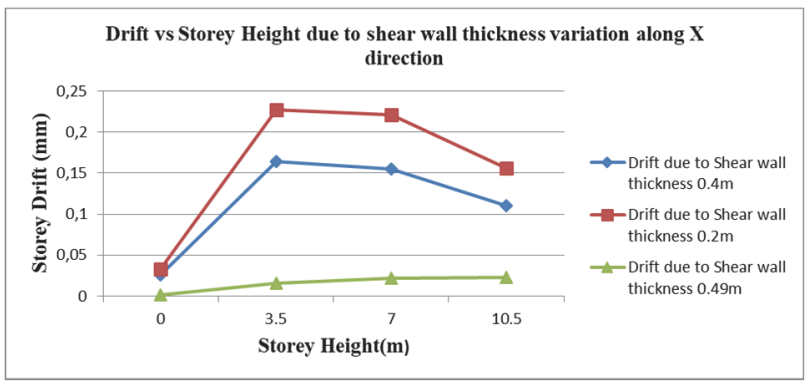

Figure 12. Drift vs. story height with variation of shear wall thickness

Variation of drift when link is drawn face to face diagonally from one corner to other bottom corner. When the link is drawn by specifying its mass and joint property in a shear wall lift system as shown in Figure 13, then there is corresponding increase in drift along the vertical axis of the joint as shown in Figure 14.
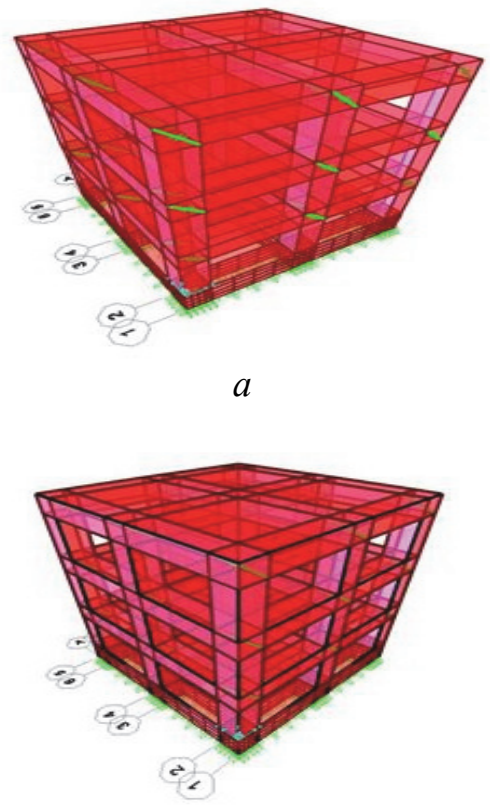

$b$

Figure 13. Shear wall system when link is connected diagonally from one corner to opposite end corner $(a)$ and when link is connected face to face along $\mathrm{X}$ axis as shown above $(b)$ 


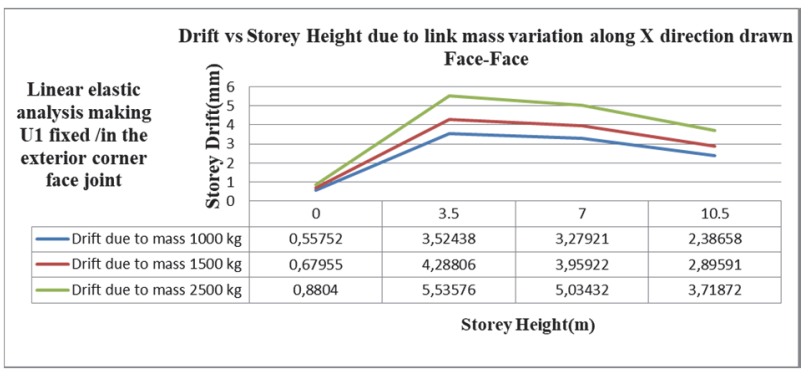

Figure 14. Drift vs. story height when link member is placed face to face diagonally along EQX direction

Link member is applied diagonally and mass is varied (Figure 14). The joint property is assigned making degree of freedom to the $\mathrm{X}$ axis as fixed as shown above.

Variation of drift in joints due to link orientation. When the link is drawn by applying the same mass and property as above but here diagonally from face to the joint section (Figure 15.), then there is also the increase in drift with the increase in link mass stiffness.

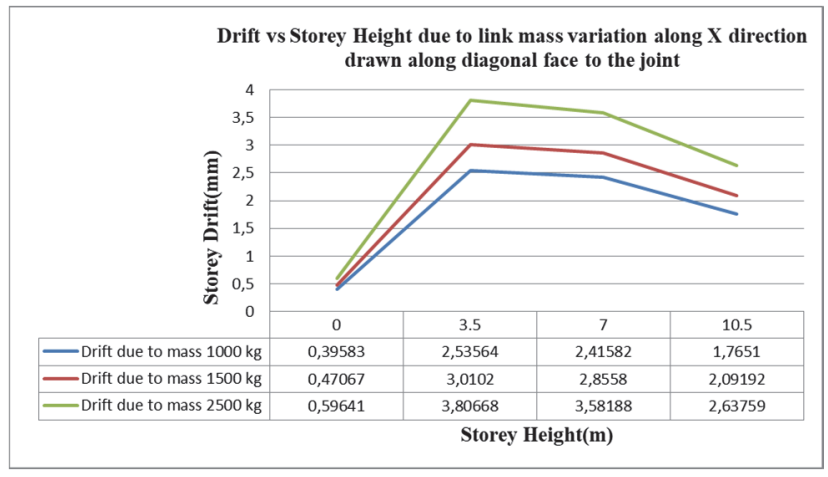

Figure 15. Drift vs. story height when link member is placed face to face diagonally along EQX direction

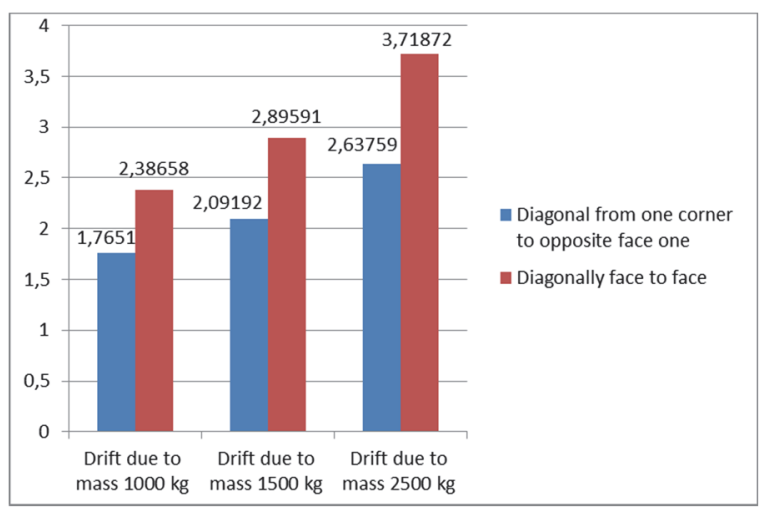

Figure 16. Comparison of drift with link face and without

If a comparison (Figure 16) is done with the link member connecting face to face and diagonally from one corner to opposite corner of the other joint at joint no. 255 of top story then it is found that the drift is more in case of link member when connected face to face.

\section{Conclusions drawn from case of shear wall system:}

1) there is decrease in inter-story drift with the increase in thickness of shear wall. But thickness should of appropriate size so that displacement and stress will be in design limit;

2) there is increase in inter-story drift and displacement with the increase in link mass stiffness when link member is placed face to face along EQ $\mathrm{X}$ direction and also when it is placed diagonally from one corner to the opposite corner of the joint;

3 ) the drift and displacement is more when link is placed face to face rather than placed diagonally.

\section{References}

1. Johnson R.P., Hope-Gill M. Semi-rigid joints in composite frames. International Association for Bridge and Structural Engineering. 1972:133-144.

2. Cabrero J.M., Bayo E. Development of practical design methods for steel structures with semi-rigid connections. Engineering Structures. 2005;(27):1125-1137.

3. Jaspart J.P. General report: session on connections. Journal of Constructional Steel Research. 2000;(55):69-89.

4. Becker R. Panel Zone Effect on the Strength and Stiffness of Steel Rigid Frames. Engineering Journal, American Institute of Steel Construction, 1975;(12):19-29.

5. Slutter R.G. Test of panel zone behavior in beamcolumn-connections. Report No. 200.81.403.1. Bethlehem, PA: Fritz Engineering Laboratory, Lehigh University; 1982.

6. Mays T.W. Application of the finite element method to the seismic design and analysis of large moment end-plate connections (PhD Dissertation). Blacksburg, VA: Virginia Polytechnic Institute and State University; 2000.

7. Ciutina A.L., Dubina D. Column web stiffening of steel beam-to-column joints subjected to seismic actions. Journal of Structural Engineering, American Society of Civil Engineers. 2008;134(3):505-510.

8. Shirsat P.S., Engelhardt M.D. Preliminary analysis of doubler plate attachment details for steel moment frames. $15^{\text {th }}$ World Conference on Earthquake Engineering. Lisboa; 2012.

9. Krawinkler H. The state of the art report on systems performance of moment resisting steel frames subjected to earthquake ground shaking. FEMA-355C. Washington, DC: Federal Emergency Management Agency; 2000.

10. Sun-Min Kim, Myoung-Ho Oh, Myeong-Han Kim, Sang-Dae Kim. Analytical Modeling and Nonlinear Analysis of Beam-Column Connection in Steel Moment Resisting Frame. Journal of Asian Architecture and Building Engineering. 2006; 5(2):309-316. https://doi.org/10.3130/ jaabe.5.309

11. Indian Standard Code IS 1893-2002. Part I. Criteria for earthquake resistant design of structures General provisions and buildings. New Delhi, India: Bureau of Indian Standards; 2002. 
12. Indian Standard Code IS 456-2000. Practice for plain reinforced concrete. New Delhi: Bureau of Indian Standards; 2000.

13. Indian Standard Code IS 13920-1993. Practice for ductile detailing of reinforced concrete structures. New Delhi: Bureau of Indian Standards; 1993

14. ACI 318-02. Building Code Requirements for Structural Concrete. American Concrete Institute, ACI Committee 318, Farmington Hills, MI; 2002.

15. Concrete Structures Standard NZS 3101. Part 1. The Design of Concrete Structures. New Zealand Standard; 1995.

16. Concrete Structures Standard NZS 3101. Part 2. The Design of Concrete Structures. New Zealand Standard; 1995.

17. Nepal Building Code NBC-205. Mandatory rules of thumb: Reinforced concrete buildings without masonry infill. Department of Building, Ministry of Physical Planning and Works, Government of Nepal; 1994.

18. Design Provisions for Earthquake Resistant Structures EN 1998-1-3:2003. Part 1. General Rules, Seismic Actions and Rules for Building. Brussels; 2003.

19. Indian Standard Code IS 800-2007. Practice for Steel Structures. Bureau of Indian standards, New Delhi; 2007.

20. Pradip S., Rajesh A., Menon D. Design of RC Beam Column Joints Under Seismic Loading. Journal of Structural Engineering. 2007; 33(6):449-457.

21. Ferdous W. Effect of Beam-Column Joint Stiffness on the Design of Beams. In: Smith S.T. (ed.) $23^{\text {rd }}$ Australasian Conference on the Mechanics of Structures and Materials (ACMSM23), Byron Bay, Australia, 9-12 December 2014

НАУЧНАЯ СТАТЬЯ

\title{
Влияние жесткости и гибкости соединения при проектировании железобетонных конструкций
}

\author{
Г.П. Ламичхане*, П. Гири \\ Университет Покхары, Pokhara Metropolitan City-30, Lekhnath, Kaski, Nepal, Post Box: 427 \\ *govindkhec@gmail.com
}

\section{История статьи:}

Поступила в редакцию: 12 ноября 2019 г. Доработана: 17 января 2020 г.

Принята к публикации: 27 января 2020 г.

\begin{abstract}
Аннотаичия
Актуальность. Соединение балки с колонной является критической областью в любой рамной конструкции, которая передает усилия в конце элементов в зоне контакта. Соединение между элементами может быть принято как жесткое, или прикрепленное, и оно не является идеальным для прогнозирования фактического поведения прикрепляемой зоны элемента, о котором необходимо позаботиться при проектировании конструкции. Memoды. В данной работе гибкость железобетонных соединений была изучена в рамках двух различных случаев: 1) железобетонное здание, состоящее из трех этажей, включая цокольный этаж, было исследовано с использованием программы SAP 2000; 2) обшивка стены третьего этажа из пустотелых бетонных ячеек с секцией колонн была также смоделирована в SAP 2000. Гибкость соединений была протестирована с точки зрения напряжений и перемещений с использованием различных подходов, таких как связь массивов, длина зоны смещения, прочностная жесткость элементов при кручении. Результаты, полученные в обоих случаях, были проанализированы, и на их основе построены графики изменения напряжений с перемещениями.

Ключевые слова: гибкость соединения; смещения длины конца; жесткость пружины при вращении; свойство массы соединения
\end{abstract}

\section{Список литературы}

1. Johnson R.P., Hope-Gill M. Semi-rigid joints in composite frames // International Association for Bridge and Structural Engineering. 1972. Pp. 133-144.

2. Cabrero J.M., Bayo E. Development of practical design methods for steel structures with semi-rigid connections // Engineering Structures. 2005. No. 27. Pp. 1125-1137.

Ламичхане Говинд Прасад, кандидат технических наук, доцент департамента инженерной школы.

Гири Праджсвал, магистрант департамента инженерной школы.
3. Jaspart J.P. General report: session on connections // Journal of Constructional Steel Research. 2000. No. 55. Pp. 69-89.

4. Becker R. Panel Zone Effect on the Strength and Stiffness of Steel Rigid Frames // Engineering Journal, American Institute of Steel Construction. 1975. No. 12. Pp. 19-29.

5. Slutter R.G. Test of panel zone behavior in beamcolumn-connections. Report No. 200.81.403.1. Bethlehem, PA: Fritz Engineering Laboratory, Lehigh University, 1982.

6. Mays T.W. Application of the finite element method to the seismic design and analysis of large moment 
end-plate connections: PhD Dissertation. Blacksburg, VA: Virginia Polytechnic Institute and State University, 2000.

7. Ciutina A.L., Dubina D. Column web stiffening of steel beam-to-column joints subjected to seismic actions // Journal of Structural Engineering, American Society of Civil Engineers. 2008. Vol. 134. No. 3. Pp. 505-510.

8. Shirsat P.S., Engelhardt M.D. Preliminary analysis of doubler plate attachment details for steel moment frames $/ / 15^{\text {th }}$ World Conference on Earthquake Engineering. Lisboa, 2012.

9. Krawinkler $H$. The state of the art report on systems performance of moment resisting steel frames subjected to earthquake ground shaking // FEMA-355C. Washington, DC: Federal Emergency Management Agency, 2000.

10. Sun-Min Kim, Myoung-Ho Oh, Myeong-Han Kim, Sang-Dae Kim. Analytical Modeling and Nonlinear Analysis of Beam-Column Connection in Steel Moment Resisting Frame // Journal of Asian Architecture and Building Engineering. 2006. Vol. 5. No. 2. Pp. 309-316. https:// doi.org/10.3130/jaabe.5.309

11. Indian Standard Code IS 1893-2002. Part I. Criteria for earthquake resistant design of structures General provisions and buildings. New Delhi: Bureau of Indian Standards, 2002.

12. Indian Standard Code IS 456-2000. Practice for plain reinforced concrete. New Delhi: Bureau of Indian Standards, 2000.
13. Indian Standard Code IS 13920-1993. Practice for ductile detailing of reinforced concrete structures. New Delhi: Bureau of Indian Standards, 1993.

14. ACI 318-02. Building Code Requirements for Structural Concrete. American Concrete Institute, ACI Committee 318, Farmington Hills, MI, 2002.

15. Concrete Structures Standard NZS 3101. Part 1. The Design of Concrete Structures. New Zealand Standard. 1995.

16. Concrete Structures Standard NZS 3101. Part 2. The Design of Concrete Structures. New Zealand Standard, 1995.

17. Nepal Building Code NBC-205. Mandatory rules of thumb: Reinforced concrete buildings without masonry infill. Department of Building, Ministry of Physical Planning and Works, Government of Nepal, 1994.

18. Design Provisions for Earthquake Resistant Structures EN 1998-1-3:2003. Part 1. General Rules, Seismic Actions and Rules for Building. Brussels, 2003.

19. Indian Standard Code IS 800-2007. Practice for Steel Structures. New Delhi: Bureau of Indian standards, 2007.

20. Pradip S., Rajesh A., Menon D. Design of RC Beam Column Joints Under Seismic Loading // Journal of Structural Engineering. 2007. Vol. 33. No. 6. Pp. 449-457.

21. Ferdous $W$. Effect of Beam-Column Joint Stiffness on the Design of Beams // 23 ${ }^{\text {rd }}$ Australasian Conference on the Mechanics of Structures and Materials (ACMSM23), Byron Bay, Australia, 9-12 December 2014 /ed. by S.T. Smith. 2014. 